\title{
Osteogenic Activity of Titanium Surfaces with Nanonetwork Structures [Retraction]
}

Xing H, Komasa S, Taguchi Y, Sekino T, Okazaki J. Int J Nanomedicine. 2014;9(1): 1741-1755.

The Editor-in-Chief and Publisher of International Journal of Nanomedicine wish to retract the published article. Concerns were raised of alleged image duplication observed in several figures within the article. Specifically:

- Figure 7A panel 10.0 M 1 week appears to be duplicated with Figure 7B panel 10.0 M 2 weeks.

- Figure 7A panel 5.0 M 1 week appears to be duplicated with Figure 7A panel 12.5 M 1 week.
- Figure 8B panel CON 4 weeks appears to be duplicated with Figure 8B panel $2.5 \mathrm{M} 4$ weeks.

Despite several attempts the authors did not respond to our queries and the decision was made to retract the article.

Our decision-making was informed by our policy on publishing ethics and integrity and the COPE guidelines on retraction.

The retracted article will remain online to maintain the scholarly record, but it will be digitally watermarked on each page as "Retracted".

\section{Publish your work in this journal}

The International Journal of Nanomedicine is an international, peerreviewed journal focusing on the application of nanotechnology in diagnostics, therapeutics, and drug delivery systems throughout the biomedical field. This journal is indexed on PubMed Central, MedLine, CAS, SciSearch ${ }^{\circledR}$, Current Contents ${ }^{\circledR} /$ Clinical Medicine,
Journal Citation Reports/Science Edition, EMBase, Scopus and the Elsevier Bibliographic databases. The manuscript management system is completely online and includes a very quick and fair peer-review system, which is all easy to use. Visit http://www.dovepress.com/ testimonials.php to read real quotes from published authors. 